DIW BERLIN

Discussion

Papers
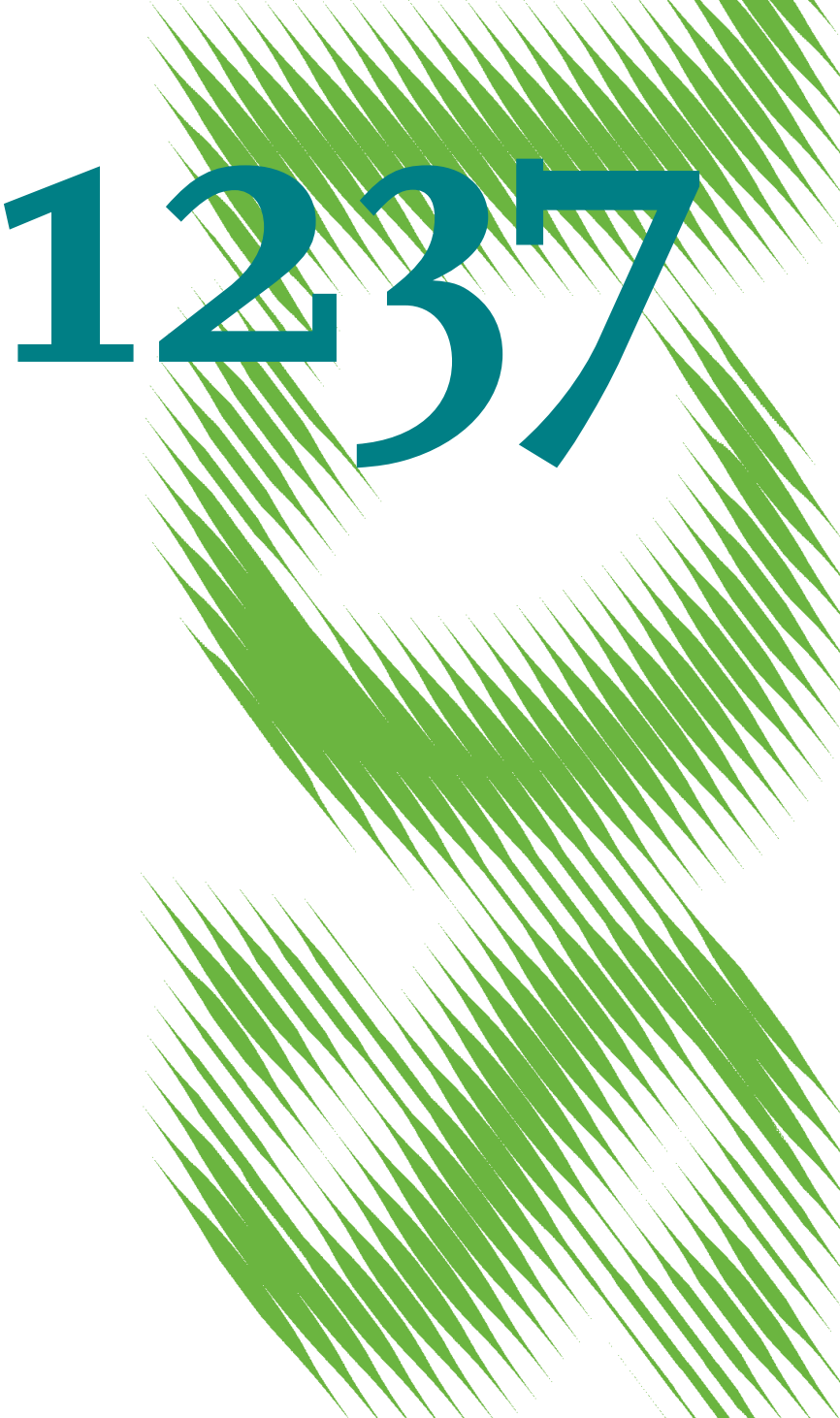

How Innovative Are Spin-Offs at Later Stages of Development?

Comparing Innovativeness of Established

Research Spin-Offs and Otherwise Created Firms 
Opinions expressed in this paper are those of the author(s) and do not necessarily reflect views of the institute.

IMPRESSUM

(C) DIW Berlin, 2012

DIW Berlin

German Institute for Economic Research

Mohrenstr. 58

10117 Berlin

Tel. $+49(30) 89789-0$

Fax +49 (30) $89789-200$

http://www.diw.de

ISSN print edition $1433-0210$

ISSN electronic edition 1619-4535

Papers can be downloaded free of charge from the DIW Berlin website:

http://www.diw.de/discussionpapers

Discussion Papers of DIW Berlin are indexed in RePEc and SSRN:

http://ideas.repec.org/s/diw/diwwpp.html

http://www.ssrn.com/link/DIW-Berlin-German-Inst-Econ-Res.html 


\title{
How Innovative Are Spin-Offs at Later Stages of Development? Comparing Innovativeness of Established Research Spin-Offs and Otherwise Created Firms
}

\author{
Anna Lejpras \\ German Institute for Economic Research (DIW Berlin) \\ DIW Berlin, 10108 Berlin, Germany, tel. +49 (0)30 $89789-348$, fax -103 \\ alejpras@diw.de
}

June 2012

\begin{abstract}
The literature argues that research spin-offs (RSOs)-enterprises originating from a university or research institute-appear to have higher innovative potential and capabilities than other start-ups, at least in the early stages of their development. Yet, little is known about the innovative performance of these companies at later development phases. Thus, the main goal of this study is to investigate whether there are any differences in R\&D and innovation behavior between established and/or mature RSOs and otherwise created firms and, if so, to what extent they are driven by networking and cooperation activities as suggested by some scholars. To this end, we employ probit regression analysis and a matching approach using survey data on more than 6,000 East German firms, among which are 179 RSOs. Our first findings suggest that established RSOs engage in R\&D and innovation activities more frequently than companies whose genesis was of another type. Nevertheless, the results obtained when accounting for collaboration measures show that the precedence of RSOs in further development stages over otherwise created firms in terms of innovativeness is related to their higher intensity of cooperation activity and close, face-to-face interactions with universities, and not to type of firm creation. Moreover, our findings reveal that cooperating in various fields may be of different importance for specific inputs and outputs of the innovation activity. Finally, based on our results, we draw some implications both for practicing managers and public policymakers.
\end{abstract}

Keywords: Spin-Offs, R\&D, Innovation, Cooperation

JEL classification: M20, L20, O30 


\section{Introduction}

Research on spin-off enterprises and their unique role in the economy is a fast-growing field (Rothaermel et al. 2007). In addition to licensing, collaboration, and consultancy, spinning off a venture from a research institution is an excellent means of commercializing scientific results. Even though many spin-offs are not significant creators of employment (Callan 2001; Cardozo and Engleman 2004; Mustar 1997, 2001; Geroski et al. 1997; Autio 1994; Stankiewicz 1994), scholars argue that these firms contribute significantly to economic and social welfare due to their important share in national and/or regional innovation systems (Cooke et al. 1997; Helm and Mauroner 2007; Mustar et al. 2008).

In fact, research spin-offs (RSOs) have a running headstart in knowledge/technology transfer, seeing that the parent organization is, by definition, a university or research institute. Hence, spin-offs, at least in the start-up phase, tend to exhibit higher innovative potential and capabilities than do firms created in other ways (Callan 2001; Helm and Mauroner 2007; Klepper and Sleeper 2005; Mustar 1998). However, little is known about the innovative behavior and performance of these firms at later stages of their development. This paper sheds some light on this issue.

Thus, the main aim of this study is to investigate empirically the innovative capabilities of established and/or mature research spin-offs, defined as firms originating from a university or research institute that have a former or present employee of that faculty as one of the founders. Specifically, our goal is to investigate whether there are any differences in R\&D and innovation behavior between RSOs and otherwise created firms in further development stages and, if so, to what extent they are driven by networking and cooperation activities as suggested by some scholars (Lejpras and Stephan 2011; Mustar 1998; Walter et al. 2006).

Our analysis is based on data on more than 6,000 companies collected in a large survey sent to 30,000 East German firms in 2004, among which are 179 RSOs. These data are unique in that they allow us to avoid the potential selection bias inherent in many previous spin-off studies based on survey data derived from the parent institutions (for a summary of the data sources used in many studies on spinoffs in OECD countries, see Callan (2001)). Moreover, in the survey, firms provided detailed information on their characteristics, performance, and activities. This information enables consideration of various measures of firm innovativeness - both inputs (R\&D activity and intensity) and outputs (product and process innovations, patents) — and collaboration activity.

To explore the differences in R\&D and innovation behavior between established RSOs and firms whose genesis was of another type, this study employs probit regression models and a matching approach. Even though matching and regression are closely related methods (both are based on the unconfoundedness assumption), regression analysis ignores the common support problem, imposes a functional form for the outcome equation, and is not as capable as is a matching approach in handling 
effects of firm heterogeneity (Caliendo and Hujer 2006; Morgan and Harding 2006). Thus, we use both methods in order to check the robustness of our results. Moreover, we provide a sensitivity analysis of our results by including firms of different age in the sample and the possible selection bias due to unobserved firm characteristics such as managerial skills.

This study contributes to the literature in three ways. First, it provides insights into R\&D and innovation behavior of established RSOs and into the sources of their innovative capabilities. Second, our sample covers several industries; therefore, our results can be easily generalized. Third, in contrast to existing research on spin-offs dealing mainly with famous clusters, such as Silicon Valley, Boston Route 128, or Cambridge (Massachusetts) (Clayton et al. 1999; Keeble et al. 1998; Saxenian 1994; Shane 2004), our analysis is based on data about firms located in a more disadvantaged region-East Germany. We think that East Germany is comparable to most averagely developed areas and/or historically less dynamic regions and, hence, we believe that the external validity of our study is higher than in the case of studies focusing on highly developed and unique high-tech environments.

In addition, our results provide interesting implications for both practicing managers and public policymakers. Exploring the differences in the innovativeness between established RSOs and firms created in other ways offers insight into how firms can strengthen their R\&D and innovative capabilities. Policymakers can draw implications for the design of policy instruments intended to promote $R \& D$ and innovation activity at the regional and/or national levels and, thus, to boost economic growth and wealth.

The next section sets out the theoretical background of the study, including a literature review and the hypotheses to be tested. Section 3 presents the dataset and first results from the descriptive analysis. Section 4 describes the methodology used in the study. Section 5 presents estimation results from probit models and propensity score matching as well as the sensitivity checks. Section 6 discusses our findings; Section 7 concludes.

\section{Literature Review and Hypotheses}

\subsection{RSOs’ Innovativeness}

In the literature, a research spin-off (RSO; also known as university, academic, or public spin-off) is frequently defined as a firm that has its origin in a notable transfer of technology or know-how from its parent organization, that being a university or research institute (e.g., Clarysse and Moray 2004; Helm and Mauroner 2007). The knowledge transfer occurs primarily via transfer of intellectual property and founding personnel, the later being former (or present) staff members of the parent institution. Moreover, the spinning-off process takes place with the assistance of (by allowing access to laboratories or through part-time employment of the future spin-off founders) or at least acceptance by the parent university and/or research institute (Callan 2001; Helm and Mauroner 2007; Klepper and 
Sleeper 2005; Meyer 2003).

Consequently, due to the support from the parent organization-especially during the research and product development phases-RSOs have the advantage of initially more developed products that are more quickly market-ready and that thus can contribute sooner to the economic development and growth of the firm than is the case for companies that start from scratch (Heirman and Clarysse 2004). Accordingly, scholars argue that RSOs have a broader experience in R\&D and exhibit a higher degree of innovation and novelty, at least in the early development stages, than companies created in other ways (for a literature overview on spin-offs, see Helm and Mauroner (2007)). However, with its focus on the firm-creation phase, the literature pays only scant attention to the innovative capabilities of RSOs in their later phases of development.

To our knowledge, there is only one paper, that by Dahlstrand (1997), which compares the innovation performance of established spin-offs with that of non-spin-off firms. The author uses data from 60 small Swedish technology-based established firms, among which are 30 spin-offs. She finds no significant difference between the two groups of companies, possibly due to the underlying data. In fact, in her dataset, two-thirds of the spin-offs emerged from private firms (so-called company spinoffs) and only one-sixth were related to universities (i.e., RSOs). Thus, the analysis is not concerned specifically with RSOs. Further, the study takes into account only one indicator of firm innovativeness - the number of patents. Other relevant indicators of firm innovation capabilities, such as R\&D activity, introducing new products, or developing new processes, are not considered. Hence, the aim of this paper is to investigate the differences in the innovative capacities and performance between established and/or mature RSOs and companies that entered the market via a different path, taking various aspects of firm innovativeness into consideration.

According to the literature, $R \& D$ and innovation tend to be persistent over time. For instance, based on two datasets - one of which covers about 3,300 firms that applied for at least one patent in the United States from 1969 to 1988 and the second of which covers approximately 1,600 firms that produced at least one major innovation in the United Kingdom at any time during 1945-1982Geroski et al. (1997) conclude that only a very small number of companies produce patents or major innovations on a regular basis. Nevertheless, the authors find that innovating is subject to "dynamic economies of scale." This means that the more innovations a firm produces, the more likely it is to continue its innovation activity. Using data on patent applications by 577 U.K. manufacturing companies that requested patents from the European Patent Office (EPO) from 1978-1991, Cefis (2003) shows that patent distributions do not display the lack-of-memory property and are path dependent. The author further finds a threshold effect represented by the first patent: the probability of a firm applying for a patent is uniformly much higher when the firm already has patents, compared to the probability of going from zero to one patent. Finally, though transition probability matrices reveal little persistence of innovativeness in general, they show strong persistence among the group of 
"great" innovators that account for a large share of requested patents.

Another strand of literature employs R\&D activity instead of patents in order to examine the persistence of firm innovativeness. For example, Mairesse et al. (1999) and Mulkay et al. (2001) explore the pattern of physical investment versus R\&D investment based on two similar samples of French and U.S. manufacturing firms during the period 1982-1993. Their results show that R\&D investment rates are highly correlated over time, even more than are physical capital investments. This reflects the fact that $R \& D$ funding is usually spent on a variety of projects, each of which runs over several years, as well as the fact that the costs for $R \& D$ personnel account for about half of $R \& D$ total expenditure. Using panel data on Spanish manufacturing firms for the period 1990-2000, Castillejo et al. (2005) show that prior R\&D experience significantly influences the current decision to engage in $R \& D$. Accordingly to the authors, this finding indicates the presence of sunk costs in R\&D activity. Moreover, although past $R \& D$ experience is important, its effect appears to depreciate fairly quickly over time. In fact, the authors find no difference between the reentry costs of a firm that last conducted $R \& D$ two or three years ago and the entry costs of a firm that had never previously performed R\&D. Finally, Peters (2006) analyzes innovative persistence for German manufacturing and service firms that innovated in the period from 1994 to 2002 using innovation expenditure (including not only intramural and extramural R\&D expenditure, but also outlays for acquisition of external knowledge, machines and equipment, training, introduction of new products to the market, etc.), as an indicator for firm innovativeness. She finds that the innovation behavior of firms is persistent to a large extent, especially in the manufacturing sector. In this sector, nearly nine out of ten firms innovating in one period continued this activity in the subsequent period; and approximately 84 percent of noninnovators continued to not innovate. Still, about half the companies experienced at least one change in their innovation behavior over the period of observation. Finally, the econometric results from this study reveal that, depending on the estimation method, one-third to one-half of the difference in the likelihood of engaging in innovation activity between former innovators and non-innovators in the manufacturing sector can be traced back to the true state dependence.

Overall, given the precedence of RSOs in terms of innovativeness over otherwise created firms at founding and the fact that firm innovativeness tends to be persistent to a large extent over time, we expect that RSOs will have higher innovative capabilities and performance in later stages of development compared to companies that entered the market through a different path. Hence, we arrive at our first hypothesis:

Hypothesis 1: At later stages of development, research spin-offs exhibit higher innovativeness than firms created in other ways. 


\subsection{Collaboration Activities and RSOs’ Innovativeness}

Many research studies highlight the significance of cooperation activity and networking for the development of major innovations (see, e.g., Best 2001; Campagni 1991; Porter 2000). Given the fact that the knowledge requirements for most R\&D projects are multidisciplinary and situation specific, it is very unlikely that one actor - either an individual or a firm - will have all the expertise needed for successful implementation of a particular R\&D undertaking (Colombo et al. 2006; Kelley et al. 2009; George et al. 2002). Thus, the underlying rationale for collaboration and networking is the acquisition and integration of additional, often complementary, knowledge and know-how that are not available within the firm but are necessary for the development of new technological capabilities and commercialization of new products (George et al. 2002; Richardson 1972; Teece 1986). Networking and collaboration not only facilitate a firm's internalization of other members' technological and market-related knowledge and capacities, but also permit a company to balance the risk of out-learning and being out-learned (Colombo et al. 2006; Walter et al. 2006; Dodgson 1992; George et al. 2002).

Moreover, cooperation and networking may significantly decrease a firm's costs, especially those relating to knowledge-creation processes. This is because, in general, the costs of a cooperative R\&D undertaking (including the firm's administrative overhead for coordinating collaboration links) are considerably lower than those of individual R\&D (George et al. 2002; Schmelter 2004). These cost reductions and innovation outputs can result in competitive advantage and improved financial performance (Grant 1998; Lerner 1994; Liebeskind et al. 1996).

Cooperation partners can take a variety of guises, ranging from other companies to financial organizations (e.g., venture capitalists, banks, business angels) and research facilities (universities, research institutes), to public institutions (local authorities, science parks, innovation centers and incubators, business development agencies). Many scholars emphasize the benefits to be derived from local linkages and "embeddedness" within a cluster or an "innovative regional milieu"; benefits that include informal and formal information flows, networking, and relationships within such a complex (Campagni 1991; Aydalot et al. 1989).

A further benefit from collaborating and networking has to do with overcoming the legitimacy problem suffered by small technology-oriented firms. Especially for young and R\&D-intensive ventures, it is difficult to demonstrate advance proof of innovative competence and economic performance. Thus, close links with high-status partners, for example, a university, may not only enable access to the partner's resources and capacities, but also provide the firm with a reputation by association for reliability and quality (Elfring and Hulsink 2003; Gübeli and Doloreux 2005; Stuart et al. 1999). Hence, cooperation and networking reduces the uncertainty and risk involved in R\&D undertakings, which may, in turn, lead to lower costs of external capital for financing R\&D (Akerlof 1970; Fama and French 2005; Greenwald et al. 1984; Townsend 1979). 
Finally, the literature stresses that integration into diverse networks of interactive relationships and partnerships enables the free flow of product-related and market-related information (George et al. 2001). Thus, cooperation activity facilitates successful commercialization of innovations (Teece et al. 1997), increases a firm's market share (Bell 1993), and improves its financial performance (Fryxell 1990). This, in turn, may result in further technological development and the introduction of additional innovative products to the market (George et al. 2002). Consequently, we propose the following hypothesis:

\section{Hypothesis 2a: Collaboration activity enhances firm innovativeness.}

More importantly, scholars argue that key to the success of spin-offs in terms of innovative and economic performance is their ability to create strategic alliances and partnerships with a variety of actors (Mustar 1998; Walter et al. 2006). Financial partnerships and interactive relationships in the fields of technology and innovation are especially important to spin-offs' growth (Mustar 1998). Using data on 149 university spin-offs, Walter et al. (2006) explore the impact of network capability (defined as a company's ability to develop and utilize interorganizational links) and entrepreneurial orientation on organizational performance. They find that both network capability and entrepreneurial orientation enhance spin-off performance. Further, network capability appears to even strengthen the relationship between entrepreneurial and spin-off performance. In sum, the study shows that university spin-offs perform better with an increasing degree of network capability. Further, in an OECD STI Review (2001) on research spin-offs, Mustar (2001) highlights the importance of spatial proximity between spin-offs and their parent institutions (primarily universities) as well as local innovation networks.

Lejpras and Stephan (2011) investigate the innovative performance of established research spin-offs compared to that of otherwise created firms. Their analysis reveals that research spin-offs in later development stages exhibit a higher degree of innovativeness than do companies created in other ways. Yet, the authors find that the higher innovative capabilities of established RSOs are not related to how the firm was created. In fact, they argue that high frequency of collaboration is a driving force behind innovativeness of firms in knowledge-intensive sectors. Hence, at the end of the day, it is not the type of firm creation, but the intensity of cooperation, that is decisive for firm innovativeness in later phases of development. This leads to the following hypothesis:

Hypothesis 2b: At later stages of development, research spin-offs and otherwise created firms with equal cooperation intensity exhibit similar innovativeness. 


\section{Data, Variables, and Descriptive Statistics}

Our analysis employs micro-level data collected via survey by the German Institute for Economic Research (DIW Berlin). ${ }^{1}$ This survey, entitled "Current Situation and Outlook of East German Firms," was sent to 30,000 firms in various sectors of the economy in East Germany in 2004; the response rate was approximately 20 percent. The questionnaire included 49 questions asking for general information about the firm and its activities, business and competition situation, and R\&D and innovation activities, as well as collaboration and networking. Moreover, companies provided information on how they were created: as (1) a spin-off from a university, (2) a spin-off from a research institute, (3) a spin-off from another company; or (4) other type of firm foundation.

In our analysis, we distinguish between the research spin-offs - that is, companies that spun off from a university or a research institute (hereinafter, spin-offs) - and firms created in other ways. The underlying dataset contains 179 spin-offs and about 6,300 otherwise created firms. Table 1 presents the descriptive statistics (means and standard deviations) for some basic characteristics, as well as $R \& D$ and innovation behavior of the firms included in the sample. On average, spin-offs appear to be significantly younger than companies created in other ways; still, the median of the founding year is quite comparable for both firm groups (1995 and 1993, respectively). Notably, only a very small fraction of companies are very young firms with an age under three years. In fact, 93 percent of spinoffs and 89 percent of otherwise created firms are older than three years; 56 and 67 percent, respectively, are older than eight years. Hence, the companies included our sample can be regarded as established firms and/or firms being in later stages of development. ${ }^{2}$ Employing on average only 15 persons, spin-offs are significantly smaller than firms founded in other ways (26 employees). Additionally, in comparison to otherwise created companies, spin-offs exhibit higher shares of employees with a university degree, higher export rates, and tend to engage in cooperation activity in the fields of basic research and product and process development more frequently. About 70 percent of spin-offs, but only 19 percent of firms created in other ways, consider proximity to research facilities as highly important.

The descriptive analysis reveals that established spin-offs have higher innovativeness than their counterparts; 85 percent of these firms engaged in R\&D activity in 2003/2004, the vast majority of them, however, conducted R\&D in an own firm. About one-quarter of spin-offs contracted R\&D to other organizations, such as other firms, universities, or research institutes. Spin-offs also exhibit higher R\&D intensity - measured in terms of both $R \& D$ deployment share and $R \& D$ expenditures over total turnover-than other types of firms. Similarly, spin-offs have better innovation output than

\footnotetext{
${ }^{1}$ The survey was carried out on behalf of the German Ministry of Education and Science.

${ }^{2}$ Thus, in further steps of the analysis, we use the whole sample. However, the results remain comparable when employing the subsamples of companies older than five years and older than eight years. For details, see Section 5.3, which provides the results of the sensitivity analysis.
} 
otherwise founded companies; 87 percent and 43 percent of those firms introduced new products (i.e., products new to the firm or improvements of existing products; $\rightarrow$ broad innovation concept) and novel products (i.e., products new to the market; $\rightarrow$ narrow innovation concept) in 2003 or 2004, respectively. Approximately, 40 percent of spin-offs established new processes and/or applied for patents in 2003/2004.

A simple mean comparison by type of firm creation, however, cannot yield an unbiased estimate of the "true" differences in $R \& D$ and innovation behavior between the firm types. Firm innovative performance depends not only on the way it was created, but also on its attributes and activities, such us size, qualified labor, economic sector, or collaboration activity. To take this fact into account, we analyze the differences in innovativeness between the spin-offs and otherwise created firms employing probit models and propensity score matching. The methodology is described in the following section; Section 5 contains the estimation results.

Table 1 ABOUT HERE

\section{Methodology}

To test our hypotheses, we conduct our empirical analysis in two stages employing two econometric approaches, that is, probit regressions and matching approach, and each of those, in turn, is estimated in two steps: (1) one that does not control for the collaboration activity, and (2) one including the cooperation measures.

Stage 1: In the first stage, we estimate the effect of being a research spin-off on the probability of firm engagement in $R \& D$ and innovative activities using probit regression models. The following formula describes our basic model:

$$
\begin{array}{ll}
Y_{i}^{*}=\alpha_{i}+\beta_{i} X^{\prime}+\gamma_{i} D^{R S O}+\varepsilon_{i}, & \text { for } i=1, \ldots, 5 ; \varepsilon_{i} \sim N(0,1), \\
& \text { if } Y_{i}^{*} \geq 0 ; Y_{i}=1, \\
& \text { if } Y_{i}^{*}<0 ; Y_{i}=0,
\end{array}
$$

where $Y_{i}^{*}$ refers to the dichotomous dependent variables: (1) engaging in the R\&D activity, (2) introducing new product (broad innovation concept), (3) establishing new-to-the-market product (narrow innovation concept), (4) developing a new production process, and (5) applying for patents in 2003 or $2004 . D^{R S O}$ is a dummy variable for being a spin-off from a university or research institute. The vector $X$ denotes a set of control variables; including them avoids the potential bias resulting from considerable heterogeneity among firms and firm subsamples discussed in the previous section. These include a dummy for affiliation with a firm group, logarithm of the age and the square of this value, logarithm of the number of employees in 2002 and the square of this value, share of employees 
with a university degree in 2002, firm's assessment of its competition situation (measured on a fivepoint Likert scale, ranging from "our firm is much weaker than our main competitors" (1), "equally strong" (3), to "much stronger" (5)), and export share in total turnover in 2002, as well as industry dummies (at the four-digit level) and dummies for firm location in an agglomeration or in a urbanized region (location in a rural region is the reference category).

In the second step, we investigate the influence of collaboration on firm innovativeness, and the extent to which the effect of foundation type on innovative performance changes when taking cooperation activity into consideration. To this end, we extend the basic model of Equation (1) in the following way:

$$
Y_{i}^{*}=\alpha_{i}+\beta_{i} X^{\prime}+\gamma_{i} D^{R S O}+\delta_{i} C^{\prime}+\varepsilon_{i}, \quad \text { for } i=1, \ldots, 5 ; \varepsilon_{i} \sim N(0,1),
$$

where the vector $C$ refers to three variables measuring the cooperation frequency in (1) basic research, (2) product development, and (3) process development, as well as (4) a dummy that takes the value 1 if a firm assessed the proximity to research facilities (universities and/or research institutes) as a highly important factor and 0 if the firm considers it irrelevant. Collaboration frequency in the particular fields is measured on a five-point Likert scale, ranging from "we do not cooperate" (1), "we cooperate sometimes" (3), to "we often cooperate" (5).

At this point, it is important to remember that, in general, regression can yield misleading findings, for several reasons. One of these involves possible model misspecification resulting from the need to impose a functional form on the outcome equation and thereby often oversimplifying these important model specification issues. Further, regression analysis ignores the common support problem, which occurs if there are fundamental mismatches between the compared groups (in our case, spin-offs and otherwise created firms) (see, e.g., Caliendo and Hujer 2006, Morgan and Harding 2006), resulting in what is basically a comparison of apples and oranges. Thus, to test our hypotheses and check the robustness of the results from probit model estimations, in the second stage of analysis, we employ a nonparametric matching approach that allows for implementing the common support restriction when comparing the $\mathrm{R} \& \mathrm{D}$ and innovation behavior of established spin-offs with that of companies created in other ways.

Stage 2: The basic idea and aim of the matching approach is to imitate a natural experiment setting, which makes such an approach particularly useful in a policy evaluation framework. In our context, for each spin-off (a treated unit), its twin - that is, an otherwise created firm with the identical combination of characteristics $X$ (a control unit) - should be assigned, whereas the model described in Equation (1) (including the notation) holds in the first step. Nevertheless, depending on the attributes $X$, it may be difficult or even impossible to identify a perfect twin for each spin-off. Hence, Rosenbaum and Rubin $(1983,1984)$ propose the concept of propensity score matching, which uses the propensity score as a matching criterion instead of the characteristics $X$. In our case, the propensity 
score $p(X)$ is the probability of being created as a spin-off given the observed characteristics $X$. Under the conditional independence assumption (CIA), a counterfactual situation of what would have happened if a firm had not been created as a spin-off can be discovered as follows:

$$
E\left(Y_{i}^{\text {Control }} \mid p(X), D^{R S O}=1\right)=E\left(Y_{i}^{\text {Control }} \mid p(X), D^{R S O}=0\right) .
$$

Given this implication, we estimate the average treatment effect on the treated: First, we estimate the propensity score using a probit model. Here, we take the same firm characteristics into consideration as in the regression model of Equation (1). To improve the matching quality, we imposed the common support restriction, that is, we dropped these controls (otherwise created firms) that have a propensity score lower than the minimum and higher than the maximum propensity score of the treated units (spin-offs) and vice versa. Second, on the basis of the propensity score, we match treated and nontreated units using one-to-one nearest neighbor matching. Third, we calculate the differences in the means of the outcome variables between spin-offs and matched control firms created in other ways (i.e., average treatment effect on the treated ATT):

$a_{A T T_{i}}=\frac{1}{N^{R S O}} \sum_{k=1}^{N^{R S O}}\left(Y_{i, k}^{N^{R S O}}-\hat{Y}_{i, k}^{\text {Control }}\right) \quad$ for $i=1,2, \ldots, 19$

where $N^{R S O}$ is the number of spin-offs. As to the outcome variables, we consider here a larger number of the measures of firm innovativeness than in the first stage of the analysis to explore more comprehensively the differences in R\&D and innovative behavior between established spin-offs and their counterparts created in other ways. These are shown at the bottom of Table 1 and range from a dummy for $R \& D$ activity, the frequency of $R \& D, R \& D$ intensity, dummy for establishing new products, to number of patent applications. Finally, the reliability of the matching was checked by testing the balance in covariates $X$ of treated and matched control firms. Here, we use the t-test on mean differences in $X$ between the firm groups (Dehejia and Wahba 2002).

In the second step, to account for the effects of cooperation activity on firm innovativeness (see Hypotheses 2a and 2b), we include the collaboration variables (as in the second step of the regression models) when calculating the propensity scores. We then proceed in the same manner as described above to determine the average treatment effect on the treated.

\section{Estimation Results}

\subsection{Determinants of Firm Innovativeness}

Table 2 sets out the marginal effects and the corresponding standard errors from probit model estimations. The statistics for the likelihood ratio tests are reported as well. All estimated models are highly significant, as indicated by the likelihood ratio tests of the null hypothesis that the slope 
coefficients are jointly zero, which are rejected at the 1 percent level using the chi-square statistic.

Note that the results from probit model estimations generally confirm the findings from the descriptive analysis about the precedence of established spin-offs over companies created in other ways in terms of innovative capabilities. The probability of engaging in $\mathrm{R} \& \mathrm{D}$, introducing new products, and applying for patents is significantly higher for spin-offs, regardless of the model specification (i.e., including or not cooperation measures in addition to the control variables described in the previous section). In the case of establishing new processes, however, the marginal effect of the dummy variable for being a spin-off becomes insignificant after involving variables measuring cooperation activity (see Model 2 vs. Model 1).

Further, the findings show that collaboration and networking are conducive to firm innovativeness. In fact, the higher the frequency of cooperation, the higher the probability of engaging in R\&D and innovating. Note that collaboration activity in particular fields appears to be of different degrees of importance for innovation input and various outputs of the firm innovation process. Cooperation in all considered fields - that is, basic research and product and process development-enhances the chances of R\&D activity as well as patent applications. For introducing a new product, frequent collaborating in product and process development tends to be relevant. When it comes to introducing new products to the market, however, it is frequent cooperation specifically in basic research and product development that is of high importance. Moreover, as one would expect, the more frequent a firm cooperates in process development, the higher the probability that it establishes a new process. Finally, firms assessing geographical proximity to universities and/or research institutes as highly important appear to engage in $R \& D$ and innovation activities more frequently than those for which this factor is irrelevant.

Table 2 ABOUT HERE

\subsection{R\&D and Innovation Behavior of RSOs Versus Otherwise Created Firms}

Table 3 sets out the results of the t-tests on the differences in outcome means - that is, R\&D and innovation activities - between the firm groups after the propensity score (nn1) matching. The balance in the covariates of spin-offs and matched firms created in other ways assures the reliability of the matching (Dehejia and Wahba 2002). ${ }^{3}$

The first three columns of Table 3 contain the results obtained when the cooperation measures are not included among the covariates in the propensity score calculations. Overall, these findings are in line with those from the naive mean comparison of spin-offs and otherwise created firms, as well as with the probit model estimations. Specifically, the fraction of spin-offs engaging in R\&D is significantly

\footnotetext{
${ }^{3}$ Detailed results on the t-test on the mean differences in the covariates after matching are available from the author.
} 
higher than the one for the matched companies founded in other ways. This holds regardless of the frequency of R\&D activity. Further, spin-offs appear to have own R\&D and conduct it in cooperation with partners from affiliated and external companies more frequently than their counterparts. Nevertheless, there are no significant differences in contracting out R\&D (e.g., to other firms, universities, or research institutes) between the two firm groups. Yet, on average, spin-offs exhibit a higher R\&D intensity - measured as both share of R\&D employees over total employment and R\&D expenditures over total sales - than their peers created in other way. Moreover, there are significant differences between the two types of companies with respect to innovation output. Spin-offs introduce product and process innovations more frequently and have a higher share of sales due to new-to-themarket products in total turnover than the matched control companies. They also apply for patents more frequently, but the average number of patents actually granted is comparable for both firm groups.

Interestingly, however, including the cooperation variables in addition to other covariates in the propensity score calculations notably changes the results (see the last three columns of Table 3 ). In fact, after controlling for collaboration and networking activities, there is not much difference in the $R \& D$ and innovation behavior of spin-offs and matched control firms created in other ways. The remaining dissimilarities have to do with $R \& D$ activity conducted occasionally, $R \& D$ carried out with partners from affiliated companies, and contracting R\&D to a university.

Table 3 ABOUT HERE

\subsection{Sensitivity Analysis}

As our study aims at investigating the differences in $R \& D$ and innovation behavior between established and/or mature research spin-offs and their otherwise created peers, we analyze to what extent our results are driven by the fact that our sample includes firms of different age (and also young companies, even if those firms comprise only a small fraction of the sample). In fact, scholars argue that start-ups overcome their liability of newness not earlier than three to five years after creation and, more usually, not until the venture is eight years old (e.g., Quinn and Cameron 1983; Kazanjian and Drazin 1990). Hence, we provide the estimation results from probit models and the matching approach for two subsamples: (1) companies older than five years and (2) those older than eight years. The respective results are shown in Table A.1 and Table A.2 of the Appendix. Notably, the findings largely correspond to those obtained when using the whole sample. Yet, in the case of establishing a new process, it seems not to matter for older firms whether they spun-off from a research facility or were created in another way.

Moreover, given the CIA assumption of the matching approach, it is important to investigate whether the inference about the treatment effects may be altered by unobservable factors (e.g., managerial 
skills). Since it is not possible to estimate the magnitude of the selection bias using non-experimental data, Rosenbaum (2002) proposes the bounding approach, which provides a way of judging how strongly unmeasured confounding variables are affecting the selection process. Accordingly, let $u_{i}$ be an unmeasured variable that affects the probability of selecting a firm $i$ into the treatment and $x_{i}$ be the observed covariates that influence the treatment and outcome variables. Then, the treatment assignment can be given by the odds:

$\frac{p_{i}}{1-p_{i}}=\exp \left(\beta x_{i}+\gamma u_{i}\right)$

Let us further assume that we have a matched pair of individuals $i$ and $j$. Rosenbaum (2002) shows that Equation (5) implies the following bounds on the odds ratio that either of the two matched individuals will receive the treatment:

$\frac{1}{\Gamma} \leq \frac{p_{i}\left(1-p_{j}\right)}{p_{j}\left(1-p_{i}\right)} \leq \Gamma$, where $\Gamma=\exp \left(\gamma\left(u_{i}-u_{j}\right)\right)$.

The parameter $\gamma$ refers to the difference in the unobserved covariates $u_{i}$ and $u_{j}$. If $\gamma=0$ and, accordingly, $\Gamma=1$, then unobserved variables have no impact on the probability of being a spin-off and, thus, there is no hidden bias. Increasing values of $\Gamma$ simulate an increasing effect of the unobservables on the selection decision. If a large value of $\Gamma$ changes the findings about the effect of being created as a spin-off, the results are sensitive to potential selection bias.

To check the sensitivity of estimated treatment effects for selected measures of firm innovative capabilities, we adopt Becker and Caliendo's (2007) procedure for bounding treatment effect estimates for binary outcomes. Table A.3 in the Appendix shows the computed Mantel-Haenszel (Mantel and Haenszel 1959) test statistics for the averaged treatment effect on the treated while setting the level of hidden bias to a certain value of $\Gamma$. Further, since the results set forth in Section 5.2 reveal a significant positive treatment effect, the corresponding significance level values $p_{-} m h+$ under the assumption of overestimation of treatment effects are presented. Under the assumption of no hidden bias $(\Gamma=1)$, the $\mathrm{MH}$ test statistics give a similar result, indicating a significant treatment effect. When increasing values of $\Gamma$, the treatment effects for engaging in $R \& D$ and introducing a new product or a completely novel product, as well as applying for a patent, remain significant (at the 10 percent level). Nevertheless, the finding of a positive effect of being a spin-off on establishing new processes appears to be less robust to the possible presence of selection bias. Here, the critical value of $\Gamma$ at which we would have to question our conclusion of a positive effect on process innovations is between 1.30 and 1.35. In other words, the critical value of $\Gamma$ is 1.35 , indicating that the results are sensitive to a bias that would increase the odds of treatment by 35 percent. However, the Rosenbaum bounds are worstcase scenarios. Thus, a critical value of $\Gamma=1.35$ does not mean that unobserved heterogeneity exists 
and that there is no effect of treatment on this outcome variable, it only means that the confidence interval for the effect would include zero if an unobserved variable caused the odds ratio of treatment assignment to differ between the established spin-offs and otherwise created firms by 1.35 .

\section{Discussion}

Scholars argue that RSOs exhibit higher innovation capabilities and performance in the early stages of their development than do firms created in other ways (Callan 2001; Klepper and Sleeper 2005; Mustar 1998). Here, we contribute to the field by comparing the innovative behavior of established and/or mature RSOs with that of otherwise created companies. The results from a naive comparison of the two firm groups reveal the precedence of RSOs in terms of innovativeness over firms whose genesis was of another type in later stages of development as well. This finding appears to hold even when accounting for various firm characteristics such as size, skilled labor, or industry (at the fourdigit level) affiliation (both in the regression models and the matching approach).

Nevertheless, including the collaboration measures in the estimations yields considerably different insights. First, we find that frequent cooperation activity in various fields strengthens R\&D and innovative performance of firms. This is because it is very unlikely that individuals and SMEs (which comprise the majority of the companies in our sample) possess all the necessary knowledge and expertise to successfully develop and commercialize innovations (Mustar 1998; Kelley et al. 2009). For introducing a product new to the market, frequent collaboration in basic research and product development appears to be important. Cooperating in product and process development contributes to introducing products new to the firm (broad innovation concept). Not surprisingly, frequent collaborating in process development is relevant for establishing process innovations. Cooperation in basic research and product and process development increases the probability of R\&D activity and patent applications. Note that the cooperation fields considered in this study can be viewed as explorative technological alliances that aim at extending a firm's collection of distinctive capabilities through organizational learning (Colombo et al. 2006). It would be interesting to also look at the effects of exploitative commercial alliances, for example, cooperation activity in the fields of sales and distribution or purchasing. This latter type of cooperation activity can enable a firm to profit from specialized assets possessed by partners that are difficult to acquire or build autonomously due to shortage of time and/or financial resource but that are needed for successful commercialization of the innovative knowledge (Colombo et al. 2006). This issue should be investigated in the future.

Second, our results with respect to collaboration and networking show that spatial proximity to research facilities (universities and research institutes) plays a considerable role in firm R\&D and innovation activity. Other studies also emphasize the importance of local firm-university links, showing that knowledge flows from university inventions appear to be geographically localized (Mowery and Ziedonis 2001). Close, face-to-face interactions with researchers and access to their 
facilities can also give companies flexibility in conducting R\&D and developing innovations since modern technology demands mastery of multifaceted disciplines (George et al. 2002; Akerlof 1970). Further, the proximity to a university enables easier access to human capital and/or highly skilled personnel (Egeln et al. 2004; Zucker et al. 1998).

Finally, the findings from the descriptive analysis show that established RSOs appear to cooperate in all considered fields and assess the proximity to research facilities as highly important more frequently than the otherwise created companies. Given this fact and the crucial role of collaboration in firm innovative capabilities discussed above, we investigate to what extent the differences in the innovativeness between RSOs and companies created in other ways in later stages of their development are driven by dissimilar collaborative behavior by means of a matching approach. The results reveal that there is not much difference in the R\&D and innovation activities between established RSOs and their matched counterparts created in other ways when accounting for cooperation measures in addition to firm characteristics, such as size or industry. Thus, the precedence of established RSOs in terms of innovative performance is related to high intensity of cooperation activities and not to how the firm was created. Similarly, scholars argue that key to the success of spinoffs in terms of innovative and economic performance is their ability to create strategic alliances and partnerships with a variety of actors (Lejpras and Stephan 2011; Mustar 1998; Walter et al. 2006).

Overall, the empirical analysis confirms the hypotheses postulated in Section 2. Moreover, the sensitivity analysis shows that our findings are largely robust to considering companies of different age and the possible selection bias due to unobserved firm characteristics such as managerial skills.

\section{Conclusions and Implications}

This study empirically investigates differences in $R \& D$ and innovation behavior between research spin-offs and otherwise created firms in later stages of development. To this end, we employ probit regression analysis and a matching approach using survey data on more than 6,000 East German firms, among which are 179 RSOs. Since measuring firm innovativeness is complex, we take into consideration various measures of innovation inputs (R\&D activity and intensity) and outputs (product and process innovations, patents).

Our results reveal that, at first glance, established and/or mature RSOs engage in R\&D and innovation activities more frequently than companies whose genesis was of another type. Nevertheless, the detailed econometric analysis shows that the precedence of RSOs in later stages of development over otherwise created firms in terms of innovativeness is related to their higher intensity of cooperation activity and not to the type of firm creation. Moreover, our study makes clear that frequent collaboration is a driving force behind firm innovativeness. Our findings suggest that cooperating in various fields may be of different importance for specific inputs and outputs of the innovation activity. For instance, frequent collaboration in basic research and product development appears to be crucial 
for introducing completely novel products (i.e., that is, products new to the market), whereas cooperating in all considered fields (i.e., basic research and product and process development) is relevant for engaging in R\&D. Finally, our study confirms the role of close, face-to-face contact with research facilities (universities or research institutes) in gaining the competitive advantage in terms of R\&D and innovative capabilities. Hence, in general, the empirical analyses confirm our postulated hypotheses.

Our findings are of relevance to both practicing managers and public policymakers. Managers can significantly improve the prospects of firm success in terms of innovativeness by enhancing networking and engaging in more frequent collaboration with a variety of partners, such as research institutes or other companies. Moreover, to sustain the innovativeness of firms in later stages of development, regional innovation policy should promote and provide incentives for firm cooperation activities. In particular, governmental $R \& D$ subsidies should be funneled toward encouraging firmuniversity collaboration as research facilities play an important role in the national and regional innovationsystems. 


\section{References}

Akerlof, G. A. (1970). The Market for "Lemons": Quality Uncertainty and the Market Mechanism. The Quarterly Journal of Economics, 84(3), 488-500.

Autio, E. (1994). New, technology-based firms as agents of R\&amp;D and innovation: an empirical study. Technovation, 14(4), 259-273.

Aydalot, P., Keeble, D., \& Groupe de recherche europ ${ }^{*}$ en sur les milieux innovateurs. (1989). High technology industry and innovative environments : the European experience. London: Routledge.

Becker, S. O., \& Caliendo, M. (2007). Sensitivity Analysis for Average Treatment Effects. Stata Journal, 7(1), 71-83.

Bell, E. R. J. (1993). Some current issues in technology transfer and academic-industrial relations: a review. Technology Analysis \& Strategic Management, 5(3), 307-321.

Best, M. H. (2001). The new competitive advantage : the renewal of American industry. Oxford: Oxford University Press.

Caliendo, M., \& Hujer, R. (2006). The microeconometric estimation of treatment effects-An overview. Allgemeines Statistisches Archiv, 90(1), 199-215.

Callan, B. (2001). Gererating spin-offs: evidence from across the OECD. STI Review, 26, 13-56.

Campagni, R. (1991). Local 'milieu,' uncertainty and innovation networks: toward a new dynamic theory of economic space. In R. Campagni (Ed.), Innovation networks: spatial perspectives (pp. 121-142). London: Belhaven Press.

Cardozo, R. N., \& Engleman, R. (2004). University technology and new business opportunities. In S. A. Zahra, C. G. Brush, P. Davidsson, J. Fiet, P. G. Greene, R. T. Harrison, et al. (Eds.), Frontiers of entrepreneurship research. Babson Park, MA: Babson College.

Castillejo, J. A. M., Aznar, R. A., Barrachina, M. E. R., \& Llopis, J. A. S. (2005). Productivity and R\&D. A non-parametric analysis. Revista De Economia Aplicada, 13(39), 47-86.

Cefis, E. (2003). Is there persistence in innovative activities? International Journal of Industrial Organization, 21(4), 489-515.

Clarysse, B., \& Moray, N. (2004). A process study of entrepreneurial team formation: the case of a research-based spin-off. Journal of Business Venturing, 19(1), 55-79.

Clayton, J., Gambill, B., \& Harned, D. (1999). The curse of too much capital: Building new businesses in large corporations. McKinsey Q, 3, 48-59.

Colombo, M. G., Grilli, L., \& Piva, E. (2006). In search of complementary assets: The determinants of 
alliance formation of high-tech start-ups. Research Policy, 35(8), 1166-1199.

Cooke, P., Uranga, M. G., \& Etxebarria, G. (1997). Regional innovation systems: Institutional and organisational dimensions. Research Policy, 26(4-5), 475-491.

Dahlstrand, A. L. (1997). Growth and inventiveness in technology-based spin-off firms. Research Policy, 26(3), 331-344.

Dehejia, R. H., \& Wahba, S. (2002). Propensity score-matching methods for nonexperimental causal studies. Review of Economics and Statistics, 84(1), 151-161.

Dodgson, M. (1992). Technological collaboration: problems and pitfalls. Technology Analysis \& Strategic Management, 4(1), 83-88.

Egeln, J., Gottschalk, S., \& Rammer, C. (2004). Location Decisions of Spin-offs from Public Research Institutions. Industry and Innovation, 11(3), 207-223.

Elfring, T., \& Hulsink, W. (2003). Networks in entrepreneurship: The case of high-technology firms. Small Business Economics, 21(4), 409-422.

Fama, E. F., \& French, K. R. (2005). Financing decisions: who issues stock? Journal of Financial Economics, 76(3), 549-582.

Fryxell, G. E. (1990). Multiple Outcomes from Product R\&D: Profitability Under Different Strategic Orientations. Journal of Management, 16(3), 633-646.

George, G., Zahra, S. A., Wheatley, K. K., \& Khan, R. (2001). The effects of alliance portfolio characteristics and absorptive capacity on performance: A study of biotechnology firms. The Journal of High Technology Management Research, 12(2), 205-226.

George, G., Zahra, S. A., \& Wood, D. R. (2002). The effects of business-university alliances on innovative output and financial performance: a study of publicly traded biotechnology companies. Journal of Business Venturing, 17(6), 577-609.

Geroski, P. A., VanReenen, J., \& Walters, C. F. (1997). How persistently do firms innovate? Research Policy, 26(1), 33-48.

Grant, R. M. (1998). Contemporary strategy analysis. New York: Blackwell.

Greenwald, B., Stiglitz, J. E., \& Weiss, A. (1984). Informational Imperfections in the Capital Market and Macroeconomic Fluctuations. The American Economic Review, 74(2), 194-199.

Gübeli, M. H., \& Doloreux, D. (2005). An empirical study of university spin-off development. European Journal of Innovation Management, 8(3), 269-282.

Heirman, A., \& Clarysse, B. (2004). How and why do research-based start-ups differ at founding? A resource-based configurational perspective. The Journal of Technology Transfer, 28(3_4), 
247-268.

Helm, R., \& Mauroner, O. (2007). Success of research-based spin-offs: state-of-the-art and guidelines for further research. Review of Managerial Science, 1(3), 237-270.

Kazanjian, R. K., \& Drazin, R. (1990). A stage-contingent model of design and growth for technology based new ventures. Journal of Business Venturing, 5(3), 137-150.

Keeble, D., Lawson, C., Smith, H. L., Moore, B., \& Wilkinson, F. (1998). Internationalisation processes, networking and local embeddedness in technology-intensive small firms. Small Business Economics, 11(4), 327-342.

Kelley, D. J., Peters, L., \& O'Connor, G. C. (2009). Intra-organizational networking for innovationbased corporate entrepreneurship. Journal of Business Venturing, 24(3), 221-235.

Klepper, S., \& Sleeper, S. (2005). Entry by spinoffs. Management Science, 51(8), 1291-1306.

Lejpras, A., \& Stephan, A. (2011). Locational conditions, cooperation, and innovativeness: evidence from research and company spin-offs. Annals of Regional Science, 46(3), 543-575.

Lerner, J. (1994). The Importance of Patent Scope - an Empirical-Analysis. Rand Journal of Economics, 25(2), 319-333.

Liebeskind, J. P., Oliver, A. L., Zucker, L., \& Brewer, M. (1996). Social networks, learning, and flexibility: Sourcing scientific knowledge in new biotechnology firms. Organization Science, 7(4), 428-443.

Mairesse, J., Hall, B., \& Mulkay, B. (1999). Firm-Level Investment in France and the United States : An Exploration of What We Have Learned in Twenty Years. Annales d'Economie et de Statistique, 55-56, 27-69.

Mantel, N., \& Haenszel, W. (1959). Statistical aspects of the analysis of data from retrospective studies of disease. Journal of the National Cancer Institute, 22(4), 719-748.

Meyer, M. (2003). Academic entrepreneurs or entrepreneurial academics? Research-based ventures and public support mechanism. $R \& D$ Management, 33(2), 107-115.

Morgan, S. L., \& Harding, D. J. (2006). Matching estimators of causal effects - Prospects and pitfalls in theory and practice. Sociological Methods \& Research, 35(1), 3-60.

Mowery, D. C., \& Ziedonis, A. A. (2001). The geographic reach of market and non-market channels of technology transfer: comparing citations and licenses of university patents. NBER Working Paper.

Mulkay, B., Hall, B., \& Mairesse, J. (2001). Firm Level Investment and R\&D in France and the United States: A Comparison. Economics Papers 2001-W2, Economics Group: Nuffield College, University of Oxford. 
Mustar, P. (1997). Spin-off enterprises. How French academics create hi-tech companies: the conditions for success and failure. Science and Public Policy, 24(1), 37-43.

Mustar, P. (1998). Partnerships, configurations and dynamics in the creation and development of SMEs by researchers. Industry and Higher Education, 217-221.

Mustar, P. (2001). Spin-offs from public research: trends and outlook. STI Review, 26, 165-172.

Mustar, P., Wright, M., \& Clarysse, B. (2008). University spin-off firms: Lessons from ten years of experience in Europe. Science and Public Policy, 35(2), 67-80.

OECD (2001). OECD STI Review (Vol. 26). Paris: OECD Publication Service.

Peters, B. (2006). Innovation and firm performance: an empirical investigation for German firms. Heidelberg New York: Physica-Verlag.

Porter, M. E. (2000). Locations, clusters and company strategy. In M. P. Feldman, G. L. Clark, \& M. S. Gertler (Eds.), The Oxford handbook of economic geography. Oxford: Oxford University Press.

Quinn, R. E., \& Cameron, K. (1983). Organizational Life Cycles and Shifting Criteria of Effectiveness: Some Preliminary Evidence. Management Science, 29(1), 33-51.

Richardson, G. B. (1972). The organization of industry. The Economic Journal, 82, 882-896.

Rosenbaum, P. R. (2002). Observational studies (2nd ed.). New York: Springer.

Rosenbaum, P. R., \& Rubin, D. B. (1983). The Central Role of the Propensity Score in Observational Studies for Causal Effects. Biometrika, 70(1), 41-55.

Rosenbaum, P. R., \& Rubin, D. B. (1984). Reducing Bias in Observational Studies Using Subclassification on the Propensity Score. Journal of the American Statistical Association, 79(387), 516-524.

Rothaermel, F. T., Agung, S. D., \& Jiang, L. (2007). University entrepreneurship: a taxonomy of the literature. Industrial and Corporate Change, 16(4), 691-791.

Saxenian, A. (1994). Regional advantage : culture and competition in Silicon Valley and Route 128. Cambridge, Mass ; London: Harvard University Press.

Schmelter, A. (2004). Entwicklungsverläufe forschungsnaher Unternehmensgründungen und deren Determinanten: Eine empirische Untersuchung auf Basis organisationsökologischer Konzepte. Die Betriebswirtschaft, 64(4), 471-486.

Shane, S. A. (2004). Academic entrepreneurship : university spinoffs and wealth creation. Cheltenham: Edward Elgar.

Stankiewicz, R. (1994). Spin-off companies from universities. Science and Public Policy, 21(2), 99- 
107.

Stuart, T. E., Hoang, H., \& Hybels, R. C. (1999). Interorganizational endorsements and the performance of entrepreneurial ventures. Administrative Science Quarterly, 44(2), 315-349.

Teece, D. J. (1986). Profiting from technological innovation: Implications for integration, collaboration, licensing and public policy. Research Policy, 15(6), 285-305.

Teece, D. J., Pisano, G., \& Shuen, A. (1997). Dynamic capabilities and strategic management. Strategic Management Journal, 18(7), 509-533.

Townsend, R. M. (1979). Optimal contracts and competitive markets with costly state verification. Journal of Economic Theory, 21(2), 265-293.

Walter, A., Auer, M., \& Ritter, T. (2006). The impact of network capabilities and entrepreneurial orientation on university spin-off performance. Journal of Business Venturing, 21(4), 541-567.

Zucker, L. G., Darby, M. R., \& Brewer, M. B. (1998). Intellectual Human Capital and the Birth of U.S. Biotechnology Enterprises. The American Economic Review, 88(1), 290-306. 


\section{Tables}

Table 1 Descriptive statistics-Spin-offs versus otherwise created firms before matching

\begin{tabular}{|c|c|c|c|c|c|c|c|}
\hline \multirow[b]{2}{*}{ Variable } & \multirow[b]{2}{*}{$N$} & \multicolumn{3}{|c|}{ Spin-offs } & \multicolumn{3}{|c|}{ Otherwise created firms } \\
\hline & & Mean & & $S D$ & $N$ & Mean & $S D$ \\
\hline Age (in years) & 179 & 9.44 & - & 8.85 & 6,336 & 18.06 & 24.26 \\
\hline age $<3$ & 179 & 0.07 & & 0.26 & 6,336 & 0.11 & 0.31 \\
\hline $3 \leq$ age $<8$ & 179 & 0.36 & + & 0.48 & 6,336 & 0.22 & 0.41 \\
\hline $8 \leq$ age $<15$ & 179 & 0.53 & & 0.50 & 6,336 & 0.47 & 0.50 \\
\hline age $\geq 15$ & 179 & 0.03 & - & 0.18 & 6,336 & 0.20 & 0.40 \\
\hline Dummy for affiliation with a firm group & 179 & 0.08 & - & 0.27 & 6,306 & 0.13 & 0.33 \\
\hline Size (in number of employees in 2002) & 175 & 14.9 & - & 21.1 & 6,119 & 26.2 & 82.2 \\
\hline size $<20$ & 179 & 0.79 & + & 0.41 & 6,336 & 0.68 & 0.47 \\
\hline $20 \leq \operatorname{size}<50$ & 179 & 0.12 & - & 0.33 & 6,336 & 0.17 & 0.38 \\
\hline $50 \leq \operatorname{size}<100$ & 179 & 0.04 & & 0.19 & 6,336 & 0.06 & 0.24 \\
\hline size $\geq 100$ & 179 & 0.04 & - & 0.21 & 6,336 & 0.08 & 0.28 \\
\hline Share of employees with university degree in 2002 & 170 & 8.47 & + & 10.60 & 5,428 & 3.34 & 11.72 \\
\hline Competition situation $^{\text {a }}$ & 162 & 3.22 & & 1.00 & 5,699 & 3.16 & 0.89 \\
\hline Export share in total turnover in 2002 & 179 & 8.54 & + & 18.50 & 6,336 & 5.25 & 14.95 \\
\hline \multicolumn{8}{|l|}{ Cooperation frequency in ... ${ }^{\mathrm{b}}$} \\
\hline basic research & 173 & 2.52 & + & 1.59 & 5,247 & 1.34 & 0.87 \\
\hline product development & 173 & 3.01 & + & 1.44 & 5,247 & 1.94 & 1.30 \\
\hline process development & 173 & 2.64 & + & 1.53 & 5,247 & 1.69 & 1.15 \\
\hline $\begin{array}{l}\text { Dummy for high importance of proximity to } \\
\text { research facilities }\end{array}$ & 179 & 0.72 & + & 0.45 & 6,336 & 0.19 & 0.39 \\
\hline Dummy for R\&D activity in $2003 / 2004$ & 179 & 0.85 & + & 0.36 & 6,336 & 0.36 & 0.48 \\
\hline ... conducted occasionally & 179 & 0.31 & + & 0.46 & 6,336 & 0.14 & 0.35 \\
\hline ... conducted regularly & 179 & 0.46 & + & 0.50 & 6,336 & 0.13 & 0.34 \\
\hline $\begin{array}{l}\text { Dummy for R\&D conducted in an own firm in } \\
2003 / 2004\end{array}$ & 179 & 0.78 & + & 0.42 & 6,336 & 0.28 & 0.45 \\
\hline ... by oneself & 179 & 0.11 & & 0.31 & 6,336 & 0.08 & 0.26 \\
\hline ... with partners from affiliated companies & 179 & 0.26 & + & 0.44 & 6,329 & 0.08 & 0.27 \\
\hline ... with external partners & 179 & 0.51 & + & 0.50 & 6,336 & 0.14 & 0.35 \\
\hline Dummy for contracting R\&D in 2003/2004 & 179 & 0.26 & + & 0.44 & 6,049 & 0.07 & 0.26 \\
\hline ... to a firm & 179 & 0.07 & + & 0.26 & 6,049 & 0.02 & 0.16 \\
\hline ... to a university & 179 & 0.15 & + & 0.36 & 6,049 & 0.04 & 0.19 \\
\hline ... to a research institute & 179 & 0.13 & + & 0.34 & 6,049 & 0.04 & 0.18 \\
\hline Deployment share in R\&D in 2003 & 171 & 37.8 & + & 32.8 & 6,001 & 6.3 & 16.1 \\
\hline $\mathrm{R} \& \mathrm{D}$ expenditures over total turnover in 2003 & 164 & 35.0 & + & 33.8 & 5,780 & 4.7 & 13.7 \\
\hline $\begin{array}{l}\text { New product in 2003/2004 (broad innovation } \\
\text { concept) }\end{array}$ & 178 & 0.87 & + & 0.34 & 6,332 & 0.62 & 0.51 \\
\hline $\begin{array}{l}\text { Novel product in 2003/2004 (narrow innovation } \\
\text { concept) }\end{array}$ & 179 & 0.43 & + & 0.50 & 6,336 & 0.14 & 0.35 \\
\hline Turnover share due to novel products in 2003 & 169 & 16.25 & + & 28.48 & 6,272 & 3.10 & 11.78 \\
\hline New processes in 2003/2004 & 171 & 0.42 & + & 0.50 & 6,166 & 0.33 & 0.47 \\
\hline Dummy for patent applications in 2004/2003 & 175 & 0.42 & + & 0.50 & 6,173 & 0.09 & 0.29 \\
\hline Number of patent applications & 174 & 1.30 & + & 2.73 & 6,151 & 0.25 & 1.49 \\
\hline
\end{tabular}

(a) Measured on a five-point Likert scale, ranging from 1 = "our firm is much weaker than our main competitors," 3 ="equally strong," to 5 = "much stronger." (b) Measured on a five-point Likert scale, ranging from 1 = "we do not cooperate," 3 = "we cooperate sometimes," to 5

$=$ "we cooperate very often." $t$-test on mean differences: $+(-)$ significantly larger (smaller) than group of otherwise created firms at

5 percent level. 
Table 2 Results from probit model estimations-Marginal effects and standard errors in parentheses of the propensity of conducting R\&D and innovation activities in 2003/2004

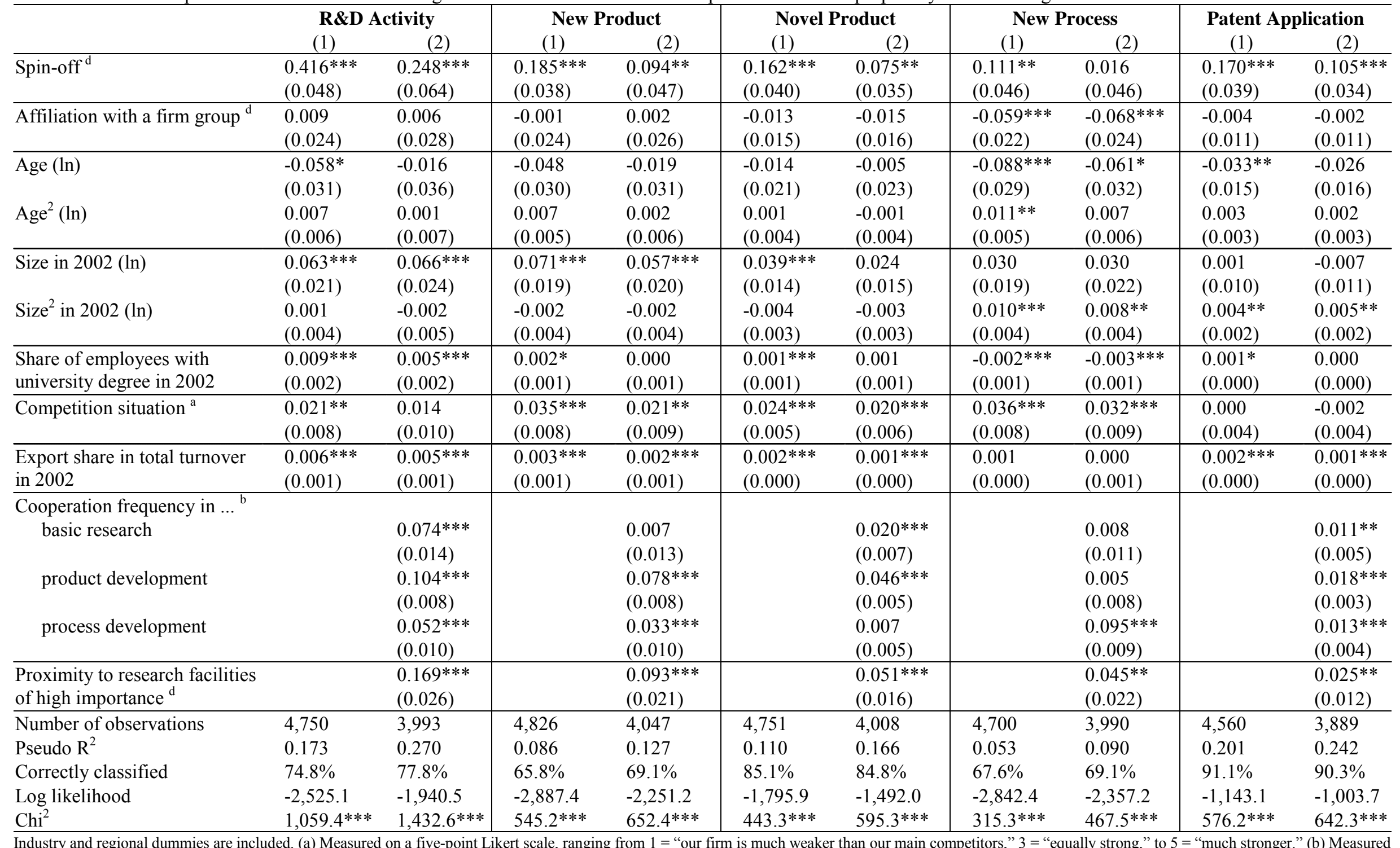

Industry and regional dummies are included. (a) Measured on a five-point Likert scale, ranging from $1=$ "our firm is much weaker than our main competitors," $3=$ "equally strong," to $5=$ "much stronger." (b) Measured on a five-po 
Table 3 Results from nearest-neighbor (nn1) matching—R\&D and innovation activities of spin-offs versus otherwise created firms after matching

\begin{tabular}{|c|c|c|c|c|c|c|}
\hline & \multicolumn{3}{|c|}{$\begin{array}{l}(1) \\
\text { not accounting for cooperation activity } \\
\text { Other }\end{array}$} & \multicolumn{3}{|c|}{$\begin{array}{c}(2) \\
\text { accounting for cooperation activity } \\
\text { Other }\end{array}$} \\
\hline Dummy for R\&D activity in $2003 / 2004$ & 0.826 & 0.477 & 5.89 & 0.829 & 0.690 & 2.20 \\
\hline ... conducted occasionally & 0.265 & 0.076 & 4.06 & 0.271 & 0.109 & 3.01 \\
\hline ... conducted regularly & 0.492 & 0.356 & 2.15 & 0.496 & 0.512 & -0.22 \\
\hline Dummy for R\&D conducted in an own firm in $2003 / 2004$ & 0.742 & 0.439 & 4.92 & 0.752 & 0.636 & 1.72 \\
\hline ... by oneself & 0.098 & 0.091 & 0.20 & 0.093 & 0.109 & -0.35 \\
\hline ... with partners from affiliated companies & 0.250 & 0.106 & 2.94 & 0.256 & 0.140 & 2.14 \\
\hline$\ldots$ with external partners & 0.492 & 0.288 & 3.32 & 0.504 & 0.442 & 0.88 \\
\hline Dummy for contracting R\&D in 2003/2004 & 0.258 & 0.189 & 1.29 & 0.264 & 0.357 & -1.44 \\
\hline .... to a firm & 0.076 & 0.098 & -0.67 & 0.078 & 0.132 & -1.27 \\
\hline ... to a university & 0.159 & 0.144 & 0.34 & 0.163 & 0.279 & -2.05 \\
\hline$\ldots$ to a research institute & 0.121 & 0.159 & -0.87 & 0.124 & 0.202 & -1.58 \\
\hline Deployment share in R\&D in 2003 & 32.902 & 12.795 & 5.83 & 33.240 & 28.217 & 1.16 \\
\hline $\mathrm{R} \& \mathrm{D}$ expenditures over total turnover in 2003 & 31.947 & 11.508 & 5.71 & 32.248 & 25.318 & 1.57 \\
\hline New product in 2003/2004 (broad innovation concept) & 0.886 & 0.712 & 3.27 & 0.884 & 0.775 & 1.93 \\
\hline Novel product in 2003/2004 (narrow innovation concept) & 0.424 & 0.280 & 2.37 & 0.426 & 0.380 & 0.66 \\
\hline Turnover share due to novel products in 2003 & 16.061 & 6.477 & 3.32 & 16.357 & 14.736 & 0.41 \\
\hline New processes in $2003 / 2004$ & 0.432 & 0.303 & 2.08 & 0.434 & 0.473 & -0.54 \\
\hline Dummy for patent applications in $2004 / 2003$ & 0.379 & 0.220 & 2.85 & 0.388 & 0.326 & 0.95 \\
\hline Number of patent applications & 1.136 & 1.121 & 0.03 & 1.163 & 1.341 & -0.44 \\
\hline
\end{tabular}

(1) The propensity score is estimated using a logit model on the basis of the following covariates: dummy for affiliation with a firm group, logarithm of age and square of this value, logarithm of number of employees in 2002 and square of this value, share of employees with a university degree in 2002, firm assessment of its competition situation, export share in total turnover in 2002, industry (at the 4-digit level), and regional dummies.

(2) In addition to the covariates contained in (1), the following variables are included: cooperation frequency in basic research and, product and process development, as well as dummy for high importance of proximity to research facilities.

Bold t-values show significant differences in R\&D and innovation activities between spin-offs and otherwise created firms. The numbers of observations are smaller than those in Table 2 due to the region of common support requirement. 


\section{Appendix}

Table A.1 Results from probit model estimations for firms older than 5 and 8 years-Marginal effects and standard errors in parentheses of the propensity of conducting R\&D and innovation activities in $2003 / 2004$

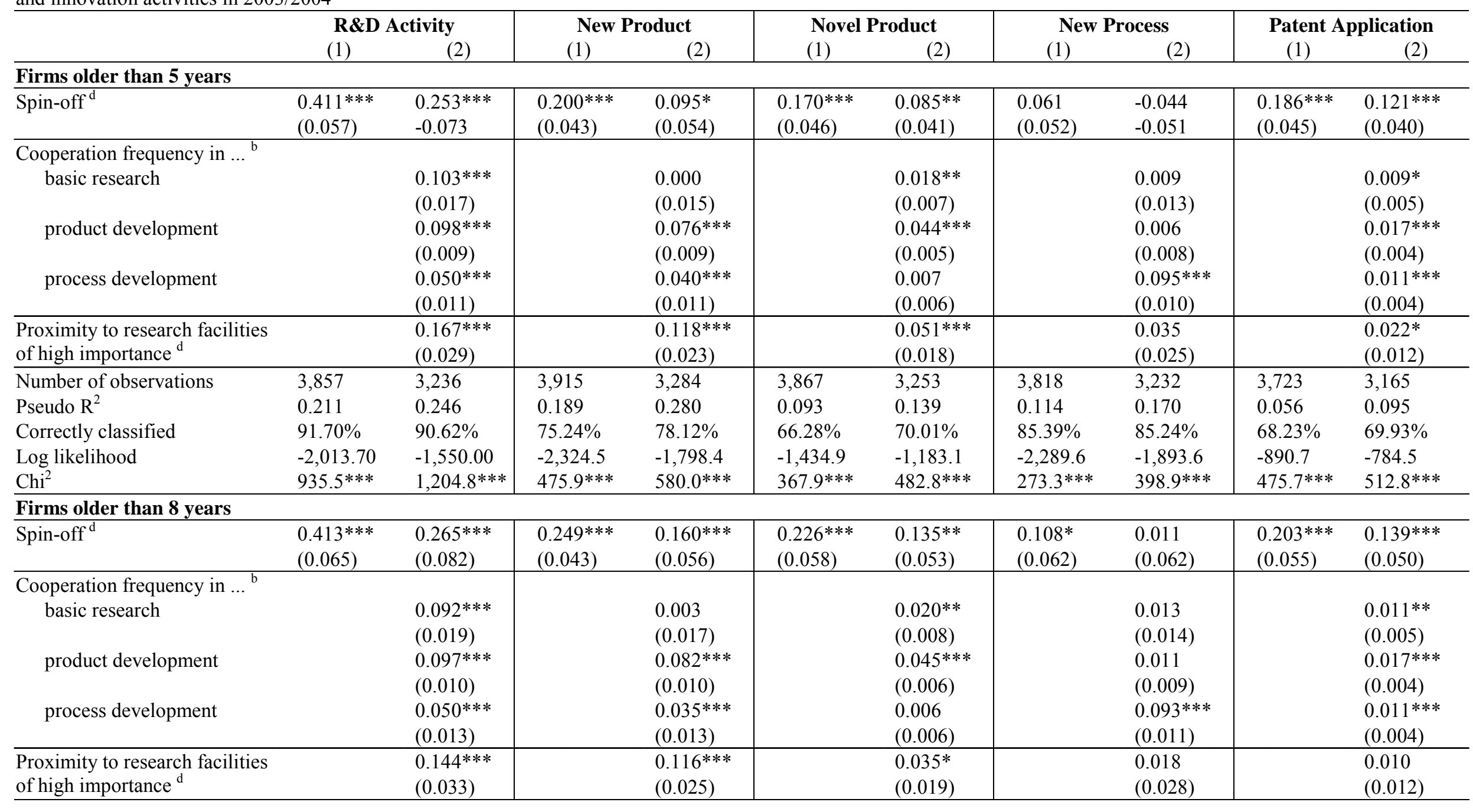


Table A.1 continued

\begin{tabular}{|c|c|c|c|c|c|c|c|c|c|c|}
\hline \multirow[b]{3}{*}{ Number of observations } & \multicolumn{2}{|c|}{ R\&D Activity } & \multicolumn{2}{|c|}{ New Product } & \multicolumn{2}{|c|}{ Novel Product } & \multicolumn{2}{|c|}{ New Process } & \multicolumn{2}{|c|}{ Patent Application } \\
\hline & (1) & $(2)$ & $(1)$ & $(2)$ & $(1)$ & $(2)$ & $(1)$ & $(2)$ & (1) & $(2)$ \\
\hline & 3,119 & 2,599 & 3,175 & 2,647 & 3,116 & 2,608 & 3,093 & 2,601 & 2,984 & 2,525 \\
\hline Pseudo $\mathrm{R}^{2}$ & 0.213 & 0.25 & 0.190 & 0.275 & 0.102 & 0.153 & 0.125 & 0.183 & 0.057 & 0.093 \\
\hline Correctly classified & $91.82 \%$ & $91.37 \%$ & $75.60 \%$ & $78.38 \%$ & $66.05 \%$ & $70.99 \%$ & $85.88 \%$ & $85.66 \%$ & $68.41 \%$ & $69.59 \%$ \\
\hline Log likelihood & $-1,614.70$ & $-1,250.50$ & $-1,871.6$ & $-1,432.2$ & $-1,124.6$ & -918.3 & $-1,848.5$ & $-1,518.3$ & -690.9 & -606.3 \\
\hline $\mathrm{Chi}^{2}$ & $759.5 * * *$ & $946.2 * * *$ & $425.1 * * *$ & $515.7 * * *$ & $320.4^{* * *}$ & $412.1 * * *$ & $223.6 * * *$ & $310.7 * * *$ & $374.4 * * *$ & $404.8 * * *$ \\
\hline
\end{tabular}

(1) The models include the following covariates: a dummy for affiliation with a firm group, logarithm of age and square of this value, logarithm of number of employees in 2002 and square of this value, share of

employees with a university degree in 2002, firm assessment of its competition situation, export share in total turnover in 2002, industry (at the 4-digit level), and regional dummies. (2) In addition to the covariates

contained in (1), the following variables are included: cooperation frequency in basic research and product and process development, as well as dummy for high importance of proximity to research facilities. (b) Measured on a five-point Likert scale, raning from $1=$ "we do not cooperate" $3=$ "we cooperate sometimes, to $5=$ "we cooperate very often." (d) For discrete change of dummy variable from 0 to 1 * $<<0.10$,** $<0.05, * * *$ $\mathrm{p}<0.01$. 
Table A.2 Results from nearest-neighbor (nn1) matching for firms older than 5 and 8 years-R\&D and innovation activities of spin-offs versus otherwise created firms after matching

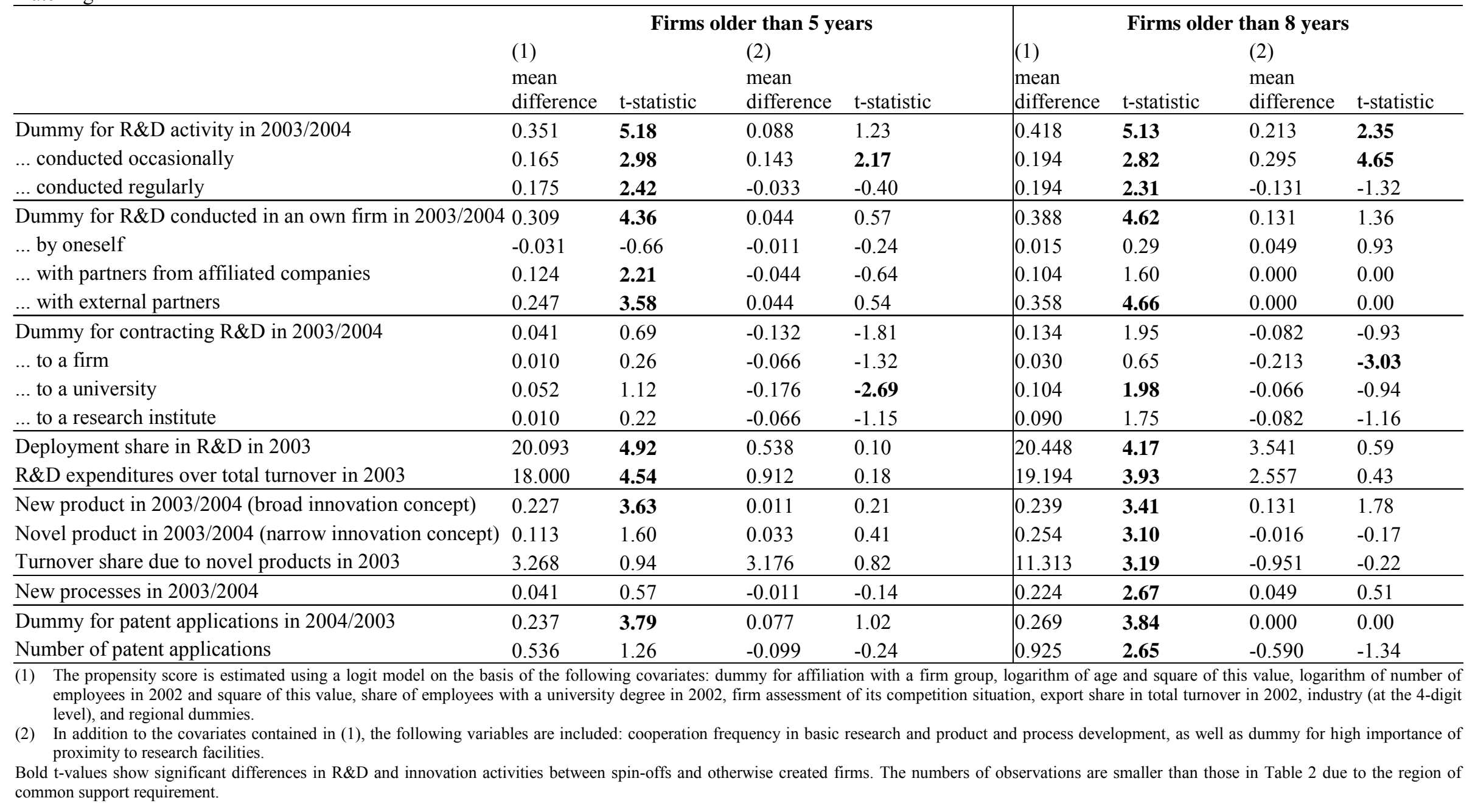


Table A.3 Rosenbaum bounds for the effects of being a spin-off on R\&D and innovation activities

\begin{tabular}{|c|c|c|c|c|c|c|c|c|c|c|}
\hline \multirow[b]{2}{*}{ Gamma } & \multicolumn{2}{|c|}{ R\&D Activity } & \multicolumn{2}{|c|}{ New Product } & \multicolumn{2}{|c|}{ Novel Product } & \multicolumn{2}{|c|}{ New Process } & \multicolumn{2}{|c|}{ Patent Application } \\
\hline & [Q_mh+; Q_mh-] & p_mh + & [Q_mh+; Q_mh-] & $\mathrm{p} \_\mathrm{mh}+$ & [Q_mh+; Q_mh-] & $\mathrm{p} \_\mathrm{mh}+$ & [Q_mh+; Q & $\mathrm{p} \_\mathrm{mh}+$ & [Q_mh+; Q_mh-] & $\mathrm{p} \_\mathrm{mh}+$ \\
\hline 1 & {$[6.13696 ; 6.13696]$} & 0.000 & {$[3.62233 ; 3.62233]$} & 0.000 & {$[2.79 ; 2.79]$} & 0.003 & {$[2.31832 ; 2.31832]$} & 0.010 & {$[3.65851 ; 3.65851]$} & 0.000 \\
\hline 1.05 & {$[5.96356 ; 6.33624]$} & 0.000 & {$[3.47195 ; 3.78841]$} & 0.000 & {$[2.61499 ; 2.97679]$} & 0.004 & {$[2.13954 ; 2.50686]$} & 0.016 & {$[3.49673 ; 3.83589]$} & 0.000 \\
\hline 1.1 & {$[5.78749 ; 6.51558]$} & 0.000 & {$[3.3226 ; 3.94089]$} & 0.000 & {$[2.44325 ; 3.15008]$} & 0.007 & {$[1.965 ; 2.68261]$} & 0.025 & {$[3.33623 ; 3.99885]$} & 0.000 \\
\hline 1.15 & [5.62017; 6.68799] & 0.000 & {$[3.18075 ; 4.08761]$} & 0.001 & {$[2.27955 ; 3.31617]$} & 0.011 & {$[1.79853 ; 2.85096]$} & 0.036 & {$[3.18356 ; 4.15537]$} & 0.001 \\
\hline 1.2 & {$[5.46079 ; 6.85406]$} & 0.000 & {$[3.04568 ; 4.22908]$} & 0.001 & {$[2.12316 ; 3.4757]$} & 0.017 & {$[1.63941 ; 3.01255]$} & 0.051 & {$[3.03798 ; 4.306]$} & 0.001 \\
\hline 1.25 & {$[5.30865 ; 7.0143]$} & 0.000 & {$[2.91679 ; 4.3657]$} & 0.002 & {$[1.97347 ; 3.62919]$} & 0.024 & {$[1.487 ; 3.16794]$} & 0.069 & {$[2.89888 ; 4.4512]$} & 0.002 \\
\hline 1.3 & {$[5.16312 ; 7.16913]$} & 0.000 & {$[2.79354 ; 4.49787]$} & 0.003 & {$[1.82991 ; 3.77712]$} & 0.034 & {$[1.34076 ; 3.31761]$} & 0.090 & {$[2.7657 ; 4.59139]$} & 0.003 \\
\hline 1.35 & {$[5.02368 ; 7.31897]$} & 0.000 & {$[2.67546 ; 4.62591]$} & 0.004 & {$[1.69198 ; 3.91991]$} & 0.045 & {$[1.20019 ; 3.462]$} & 0.115 & {$[2.63796 ; 4.72696]$} & 0.004 \\
\hline 1.4 & {$[4.88983 ; 7.46416]$} & 0.000 & {$[2.56214 ; 4.75012]$} & 0.005 & {$[1.55927 ; 4.05794]$} & 0.059 & {$[1.06487 ; 3.60149]$} & 0.143 & {$[2.51524 ; 4.85823]$} & 0.006 \\
\hline 1.45 & {$[4.76116 ; 7.60503]$} & 0.000 & {$[2.4532 ; 4.87077]$} & 0.007 & {$[1.43139 ; 4.19153]$} & 0.076 & {$[0.9344 ; 3.73644]$} & 0.175 & {$[2.39716 ; 4.9855]$} & 0.008 \\
\hline 1.5 & {$[4.63729 ; 7.74186]$} & 0.000 & {$[2.34832 ; 4.98809]$} & 0.009 & {$[1.30798 ; 4.32099]$} & 0.095 & {$[0.808443 ; 3.86714]$} & 0.209 & {$[2.28338 ; 5.10903]$} & 0.011 \\
\hline
\end{tabular}

Q_mh+ and Q_mh-are Mantel-Haenszel test statistics under assumptions of overestimated and underestimated treatment effects. p_mh+ refers to significance levels under assumption of overestimation of treatment effects. 